\title{
HEPATOPROTECTIVE ACTIVITY OF EXOGENOUS RNA
}

\author{
I. O. SHMARAKOV ${ }^{1}$, T. V. MARCHYSHAK ${ }^{1}$, V. L. BORSCHOVETSKA ${ }^{1}$, \\ M. M. MARCHENKO', Z. YU. TKACHUK \\ ${ }^{1}$ Yuriy Fedkovych Chernivtsi National University, Ukraine; \\ e-mail: igor.shmarakov@gmail.com; \\ ${ }^{2}$ Institute of Molecular Biology and Genetics, \\ National Academy of Sciences of Ukraine, Kyiv; \\ e-mail: ztkachuk@yahoo.com
}

\begin{abstract}
Hepatoprotective activity of Nuclex, a pharmaceutical composed of low-molecular yeast RNA, was investigated during acute and chronic thioacetamide-induced hepatotoxicity. It is demonstrated, that Nuclex administration at a dose of $200 \mathrm{mg} / \mathrm{kg}$ during acute and chronic liver injury produces hepatoprotective effect, which is associated with decrease in liver parenchyma lesions and in its inflammatory infiltration. Nuclex application attenuates thioacetamide-induced free radical damage of hepatic biopolymers, expressed in the reduction of TBA-reactive products, carbonyl derivatives, and recovery of protein thiol groups and reduced glutathione levels.
\end{abstract}

Key words: Nuclex, thioacetamide, hepatotoxicity, hepatoprotective effect of exogenous RNA, C57BL6/J mice.

$\mathrm{T}$ herapeutic application of oligonucleotides is a leading trend in correction of metabolic disorders and related pathologies and is perceived as a unique foundation of innovative biomedicine [1]. Exogenous oligonucleotides and products of their partial hydrolysis, synthetic poly- and oligonucleotides display a vast spectrum of biological effects, including cellular metabolism stimulation with activation of endogenous synthesis of nucleic acids, regulatory proteins and enzymes, increase in cellular mitotic activity, stimulation of reparation processes and ATP synthesis [2]. It has been demonstrated [3-5] that these biological effects are based on ability of the compounds belonging to this class to modulate messenger RNA activity at post-transcriptional and translational levels [4], as well as to affect $\mathrm{Ca}^{2+}$ binding proteins, protein kinases, interferons and cytokines [5-9].

Nuclex and Nucleinate, which are pharmaceuticals based on yeast RNA oligoribonucleotides, have been demonstrated to be efficient therapeutics for correction of such liver pathologies as chronic viral hepatitis, nonalcoholic steatohepatitis, and metabolic syndrome and related obesity and insulin resistance [10]. Nevertheless, there are no data as to hepatoprotective qualities of exogenous RNA under acute and chronic hepatotoxic lesions. The aim of the pre- sent work was to evaluate hepatoprotective effects of yeast RNA-based Nuclex pharmaceutical under thioacetamide liver toxicity in mice.

\section{Materials and Methods}

The experiments were conducted on C57BL6/J mice with body mass of $18-25 \mathrm{~g}$ and aged $2.5-3$ month at the beginning of the experiment. Animal keeping, handling and manipulating were in accordance with the article 26 of the Law of Ukraine No 3447-IV 21.02.2006 "On the Protection of Animals from Cruelty", "European Convention for the Protection of Vertebrate Animals Used for Experimental and Other Scientific Purposes" (Strasbourg, 1986) and with regard to NIH Guide for the Care and Use of Laboratory Animals [11].

Thioacetamide-induced hepatotoxicity was used to model toxic lesions of the liver in mice [12]. The acute toxic lesions of the liver were induced by intraperitoneal injections of thioacetamide (TAA) in a dose of $500 \mathrm{mg} / \mathrm{kg}$. The animals were divided into the following groups: I (negative control) - the animals were administered normal saline $(0.9 \% \mathrm{NaCl})$ every $12 \mathrm{~h}$; II (positive control I) - the animals were administered a $500 \mathrm{mg} / \mathrm{kg}$ dose of TAA solution intraperitoneally; III (experimental group) - the animals were administered a $500 \mathrm{mg} / \mathrm{kg}$ dose of TAA 
solution intraperitoneally, and then $200 \mathrm{mg} / \mathrm{kg}$ doses of Nuclex (exogenous ribonucleotides) solution orally every $12 \mathrm{~h}$ for the period of $48 \mathrm{~h}$; IV (positive control II) - the animals were administered a $500 \mathrm{mg} /$ $\mathrm{kg}$ dose of TAA solution intraperitoneally, and then $50 \mathrm{mg} / \mathrm{kg}$ doses of Glutargin (arginine glutamate, the reference substance) solution orally every $12 \mathrm{~h}$ for the period of $48 \mathrm{~h}$.

The animals ( 5 for each group) were slightly anesthetized by ether and euthanized after $48 \mathrm{~h}$ of TAA administration.

The chronic toxic lesions of the liver were induced by intraperitoneal injections of TAA in doses of $150 \mathrm{mg} / \mathrm{kg}$ twice a week for 9 weeks. The animals were divided into the following groups: I (negative control) - the animals were administered normal saline $(0.9 \% \mathrm{NaCl}) 5$ times a week; II (positive control I) - the animals were administered $150 \mathrm{mg} /$ $\mathrm{kg}$ doses of TAA solution intraperitoneally twice a week; III (experimental group) - the animals were administered $150 \mathrm{mg} / \mathrm{kg}$ doses of TAA solution intraperitoneally twice a week, and $200 \mathrm{mg} / \mathrm{kg}$ doses of Nuclex solution orally 5 times a week; IV (positive control II) - the animals were administered a $500 \mathrm{mg} / \mathrm{kg}$ dose of TAA solution intraperitoneally, and then $50 \mathrm{mg} / \mathrm{kg}$ doses of Glutargine (arginine glutamate) solution orally 5 times a week.

The animals ( 5 for each group) were slightly anesthetized by ether and euthanized after 9 weeks of TAA administration. The liver was excised and blood sampled from inferior vena cava. The blood samples were sedimented at $3000 \mathrm{~g}$ for $10 \mathrm{~min}$ in order to obtain serum.

The degree of the liver damage was evaluated via the blood serum enzymatic activity of $\gamma$-glutamyl transpeptidase (GGT, EC 2.3.2.2), a membrane-associated enzyme in hepatocytes, with a standard kit (Felicit-Diagnostika, Ukraine) in accordance with instructions and was expressed as $\mu \mathrm{kat} / \mathrm{l}$. Myeloperoxidase activity (MPO, EC 1.11.2.2) was assayed after [13] as an indicator of parenchyma infiltration by neutrophils. Briefly, $50 \mathrm{mg}$ of liver tissue was homogenized in $500 \mathrm{ml}$ of potassium-phosphate buffer (pH 7.4) followed by centrifugation at $15000 \mathrm{~g}$ for $5 \mathrm{~min}$, then resuspended in 10 volumes of $50 \mathrm{mM}$ potassium-phosphate buffer ( $\mathrm{pH} 6.0$ ) with $0.5 \%$ of hexadecyltrimethylammonium bromide and incubated for $2 \mathrm{~h}$ at $60^{\circ} \mathrm{C}$. After ultrasound processing the samples were put through a triple freezing-thawing cycle and processed with ultrasound further for $10 \mathrm{~min}$, followed by centrifugation at $15000 \mathrm{~g}$ and
$4{ }^{\circ} \mathrm{C}$ for $15 \mathrm{~min}$. The supernatant $(300 \mu \mathrm{l})$ was mixed with $300 \mu \mathrm{l}$ of dianisidine dihydrochloride $(10 \mathrm{mg} /$ $\mathrm{ml}$ in potassium-phosphate buffer), $300 \mu \mathrm{l}$ of $0.3 \%$ of hydrogen peroxide $\left(\mathrm{H}_{2} \mathrm{O}_{2}\right)$, and absorbance at $\lambda=405 \mathrm{~nm}$ was measured for $1 \mathrm{~min}$. Myeloperoxidase activity was expressed as $\Delta \mathrm{D} \times \mathrm{min}^{-1} 1 \times \mathrm{mg}^{-1}$ of protein.

Oxidative damage of biomolecules was evaluated based on reduced glutathione levels, TBAreactive substances content (aldehydic substances reacting with thiobarbituric acid (TBA)), protein carbonyl derivatives, and protein thiol derivatives in liver tissue. TBA-reactive substances content was measured after [14] and expressed as $\mathrm{nmol} / \mathrm{mg}$ of protein. Protein carbonyl derivatives content was measured after [15] and expressed as nmol/mg of protein. Protein -SH group content was measured after [16] and expressed as nmol/mg of protein. Reduced glutathione content in liver was assayed after Butler. The level of reduced glutathione was determined with calibration against standard solutions of reduced glutathione $(0.1 \mathrm{mmol} / 1$ through $5 \mathrm{mmol} / \mathrm{l})$ and expressed as nmol/mg of protein [17]. Protein concentration was assayed after Lowry et al. [18].

Statistical data processing was done with Microsoft Excel software using one-way analysis of variance followed by Tukey's honest significant difference test. The differences were considered significant if $P \leq 0.05$. In graphic representation, the values are indicated by Latin letters $(a, b, c)$ if differing significantly from each other, e.g. values indicated by $a$ differ significantly from those indicated by $b$ and $c$. Values indicated by the same letter do not differ significantly between themselves.

\section{Results and Discussion}

The results of our studies demonstrate that Nuclex (low molecular weight exogenous RNA) administration to mice in doses of $200 \mathrm{mg} / \mathrm{kg}$ at $12 \mathrm{~h}$ intervals attenuates the hepatotoxicity caused by a single dose of thioacetamide $(500 \mathrm{mg} / \mathrm{kg})$ at $48 \mathrm{~h}$ of the experiment (Fig. 1 and 2). The hepatoprotective effect is manifested as $40 \%$ decreased blood serum $\gamma$-glutamyl transpeptidase activity in comparison to that of animals of group II, in which this parameter was nearly double that of the control group (group I) (Fig. 1, A). On the other hand, myeloperoxidase activity (which is an indicator of inflammatory infiltration of liver parenchyma by neutrophils) did not differ significantly under Nuclex administration and in control conditions (Fig. 1, B). Animal group re- 
ceiving clinically tested and approved hepatoprotective Glutargine pharmaceutical was used as positive control (group IV). The results demonstrated that Nuclex administration had hepatoprotective effect that did not differ by tested parameters from that of Glutargine (Fig. 1).

Just as no signs of toxic liver parenchyma lesions and its inflammatory infiltration were observed under Nuclex administration, so no indications of oxidative damage to liver biopolymers were detected either (Fig. 2). It has been shown that hepatotoxic potential of thioacetamide is realized through free radical prooxidative mechanism [19], which was evidenced by oxidative damage to liver biopolymers in our experiment (Fig. 2). In contrast to this, Nuclex administration was followed by attenuation of oxidative damage to protein and non-protein thiol groups (Fig. 2, A, C), decreased levels of protein carbonyls and secondary products of lipid peroxidation (Fig. 2, $B, D)$. The levels of protein and non-protein thiol groups content in animals receiving Nuclex administration did actually reach that of negative control group (Fig. 2, A, C). On the other hand, while TBAreactive substances and protein carbonyl derivatives content was significantly lower in comparison to that of positive control group (group II), they did not reach those of the negative control group (group I).

The hepatoprotective effect of Nuclex that we observed in acute hepatotoxicity model was also confirmed in the experiments in conditions of chronic toxic liver damage (Fig. 3, 4). The results demonstrate the profound hepatoprotective effect of $200 \mathrm{mg} / \mathrm{kg}$ doses of Nuclex in 9 week long oral administration course and attenuation of free-radical liver biopolymers oxidation induced by prolonged chronic hepatotoxin administration. For instance, reduced glutathione's, protein thiol groups', and carbonyl protein derivatives' levels in animals that received both thioacetamide and Nuclex administrations were within margins of those of the control group indices (Fig. 4). The absence of indications for thioacetamide-iduced oxidative damage to liver biopolymers under conditions of hepatoprotectors' administration, as well as their profound hepatoprotective effect, were strengthened by lower levels of $\gamma$-glutamyl transpeptidase activity in blood serum and myeloperoxidase activity in liver parenchyma of animals of these experimental groups (Fig. 3).

Although we have not investigated the possible molecular mechanisms involved in the described phenomena, we did clearly demonstrate the profound hepatoprotective qualities of oligoribonucleotides composing the Nuclex pharmaceutical.

The results obtained by us do not contradict the literature data as to improvement of clinical markers in patients with toxic hepatitis of unclear etiology with possible complications by comorbidities under administration of similar pharmaceutical (Nuclein-
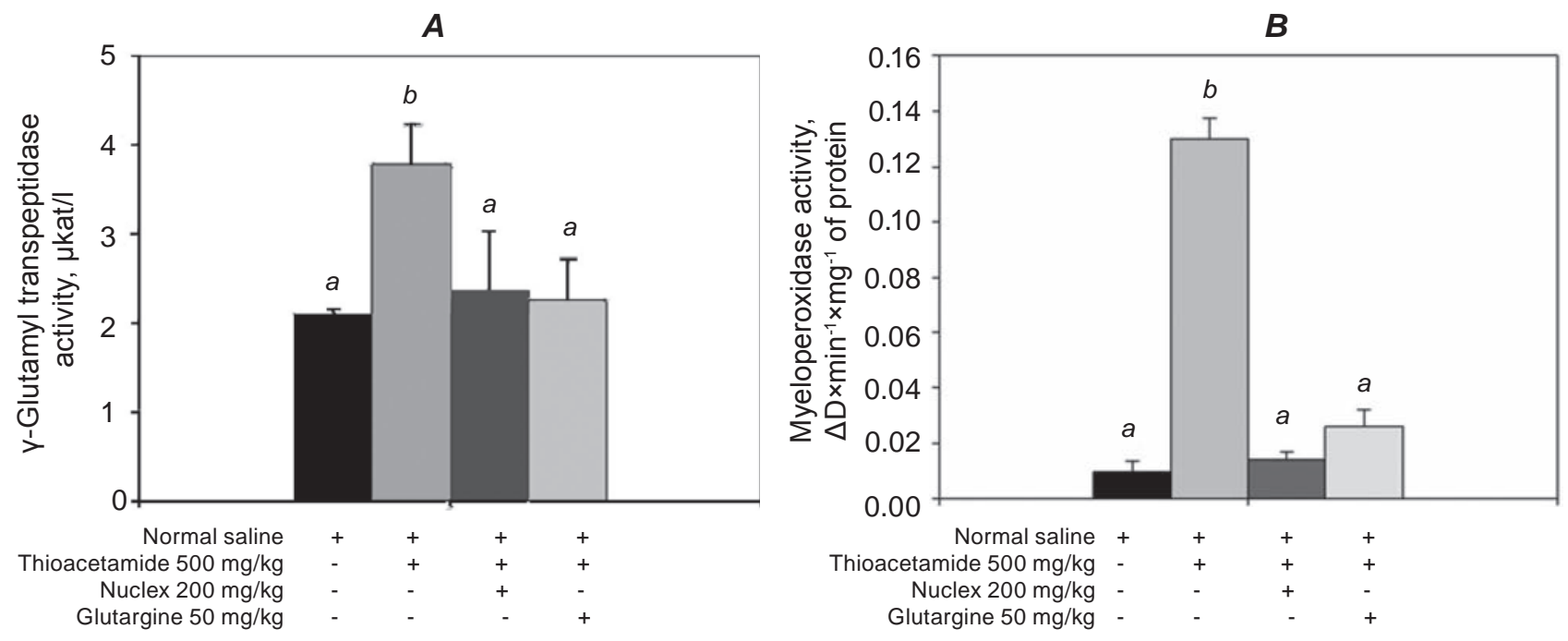

Fig. 1. Biochemical markers of liver lesions under acute thioacetamide-induced hepatotoxicity. Blood serum $\gamma$-glutamyl transpeptidase (A) and liver parenchyma myeloperoxidase (B) activities were determined at $48 \mathrm{~h}$ post intraperitoneal injection of normal saline and thioacetamide, and oral administration of Nuclex and Glutargine; the values indicated by letters $(a, b)$ differ significantly from each other. Here and below in Fig. 2-4 $P \leq 0.05$; all the values are presented as means + standard deviation, $n=5$ for each group 
$A$

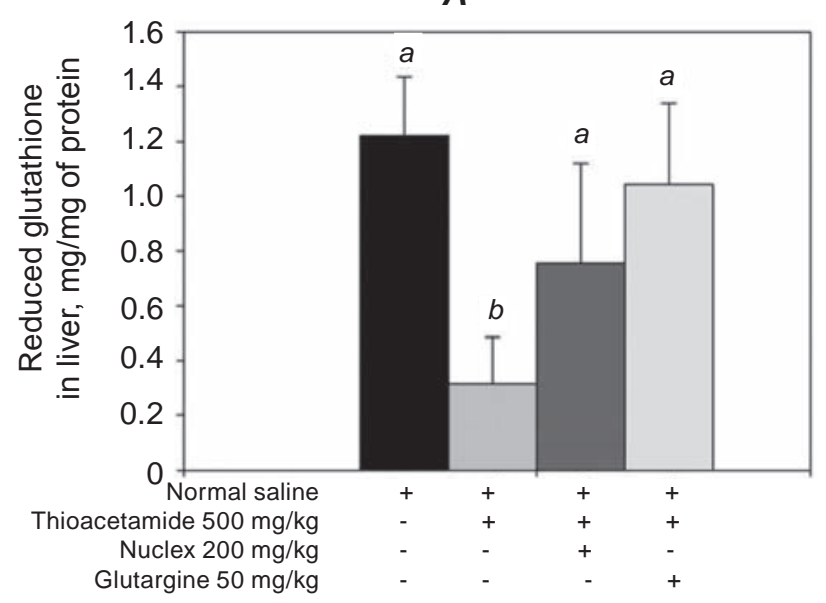

C

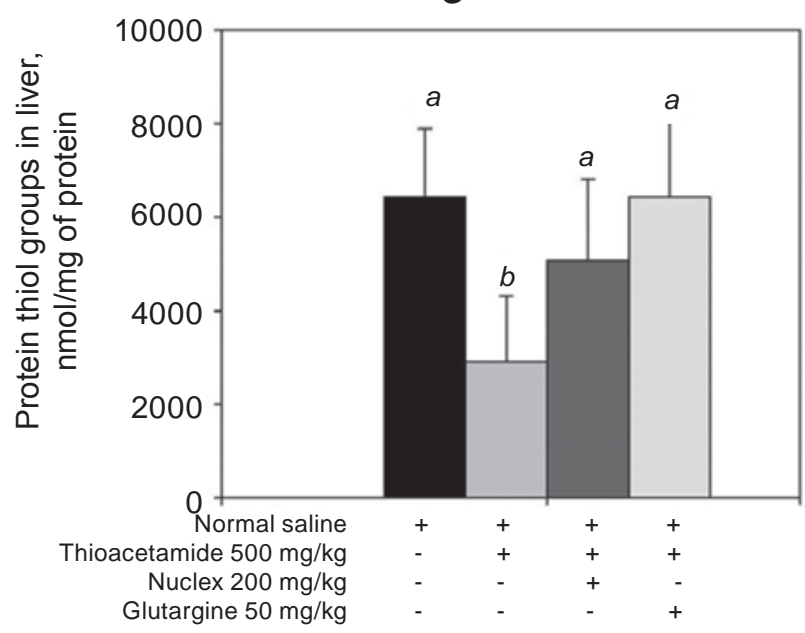

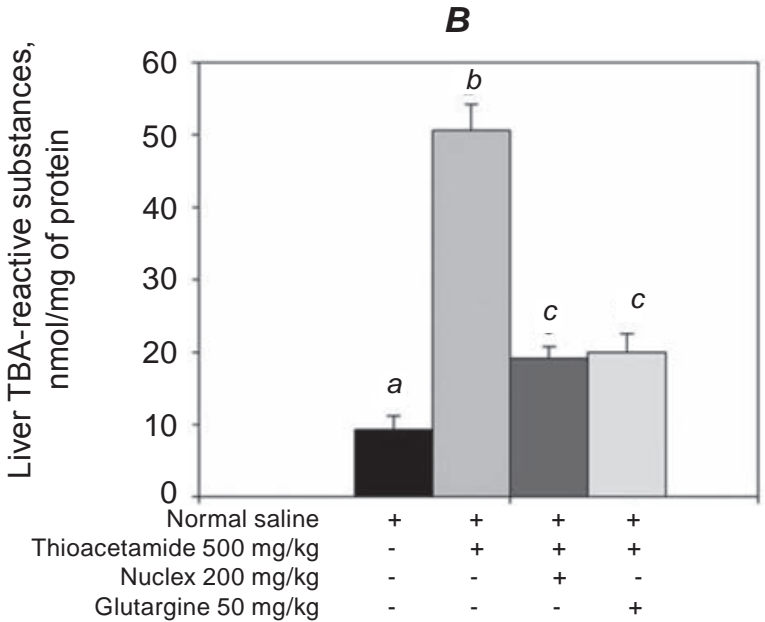

D

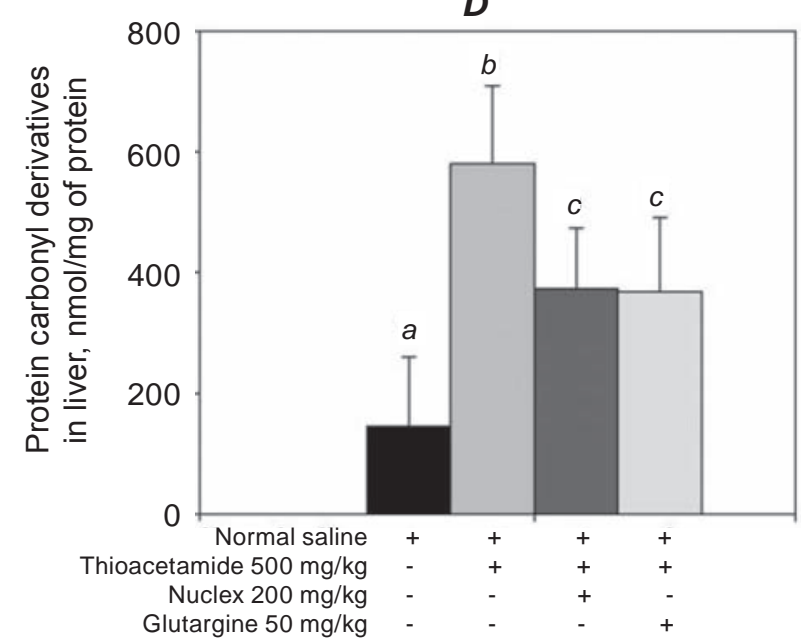

Fig. 2. Levels of products of oxidative damage to hepatic cellular biomolecules in mice under acute thioacetamide-induced hepatotoxicity. Reduced glutathione (A), TBA-reactive substances (B), protein thiol groups (C), and carbonyl derivatives $(D)$ levels were determined in liver tissue at $48 \mathrm{~h}$ post intraperitoneal injection of normal saline and thioacetamide, and oral administration of Nuclex and Glutargine; the values indicated by letters $(a, b, c)$ differ significantly from each other

ate) in addition to primary detoxication therapy [20]. On the other hand, our studies prove the exclusive hepatoprotective qualities of Nuclex when administered in monotherapy to mice under experimental hepatotoxicity model conditions.

These results demonstrate the decrease of lesions in the liver parenchyma and inflammatory infiltration of liver by neutrophils under Nuclex administration and correlate well with data concerning anti-inflammatory effect of yeast RNA investigated on local inflammation model [21]. Moreover, the decreased levels of TBA-reactive substances do not contradict membrane-stabilizing properties of oli- goribonucleotides as had been described on in vitro model systems [22]. In contrast to this, in the in vivo model system, which was used in our experiment, not just the hepatocytes take part in hepatotoxic processes in the role of the primary effector cells, but various populations of non-parenchymal cells are also involved [22, 23]. It is sensible to assume that Nuclex' properties as a modulator of signal transduction are underlying its apparent hepatoprotective effect, which in the case of hepatotoxicity affects expression and signaling of proinflammatory cytokines and profibrotic growth factors that are produced and secreted by non-parenchymal liver cells. The most 

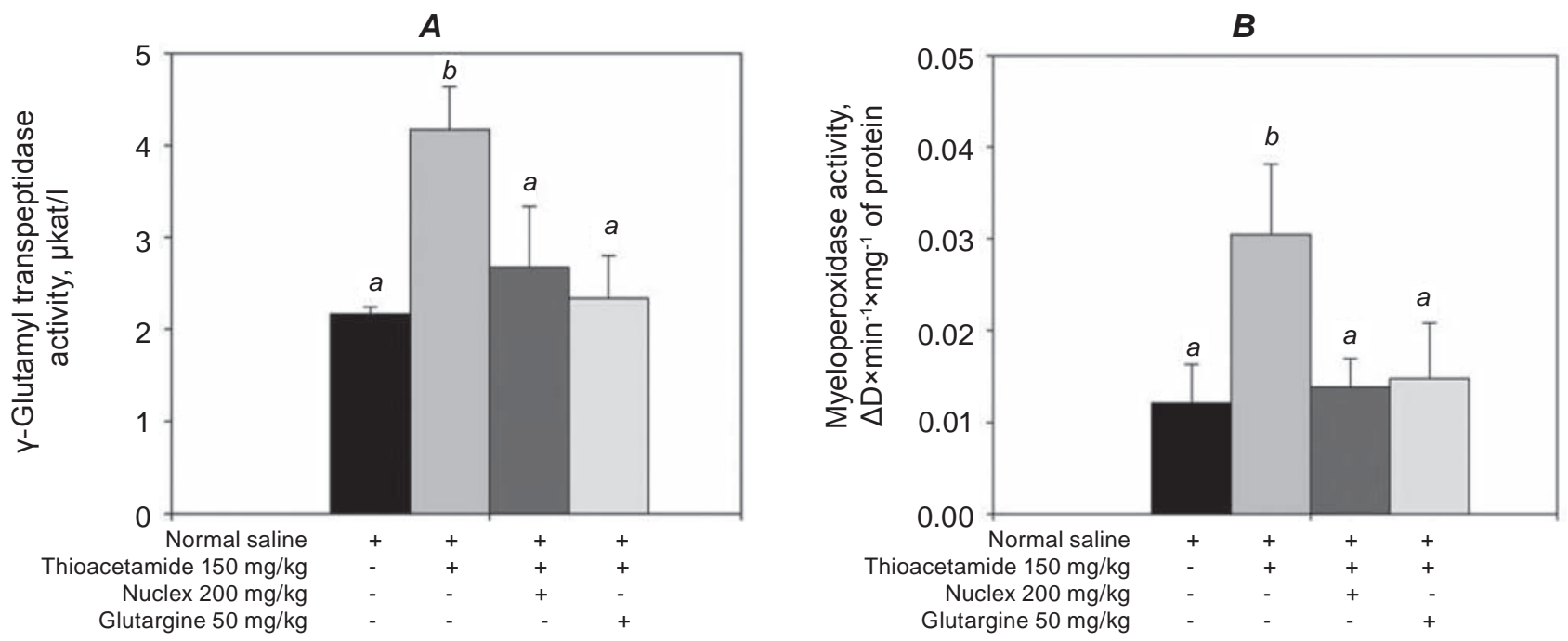

Fig. 3. Biochemical markers of liver lesions under chronic thioacetamide-induced hepatotoxicity. Blood serum $\gamma$-glutamyl transpeptidase (A) and liver parenchyma myeloperoxidase (B) activities were determined post 9 week long course of intraperitoneal injection of normal saline and thioacetamide, and oral administration of Nuclex and Glutargine; the values indicated by letters $(a, b)$ differ significantly from each other

involved in these pathways are Kupffer cells (resident liver macrophages) as the main producers of pro-inflammatory interleukin 6 (IL-6) and tumor necrosis factor (TNF $\alpha)$, as well as hepatic stellate cells, which produce large quantities of hepatocyte growth factor (HGF) and profibrotic transforming growth factor (TGF $\alpha, T G F \beta)$ upon activation [22]. The proof of interdependence between the effect we have shown and the abovementioned signal molecules is the obvious subject for our further studies.

Thus, the results of this work demonstrate that Nuclex administration to mice $(200 \mathrm{mg} / \mathrm{kg})$ under acute and chronic liver lesions models is followed by profound hepatoprotective effect, decreased levels of markers of damage to liver parenchyma and its inflammatory infiltration. The hepatoprotective effect of Nuclex (exogenous RNA) pharmaceutical attenuates thioacetamide-induced free-radical damage to liver biopolymers, decreases the levels of TBA-reactive substances and carbonyl derivatives, and restores the levels of protein thiol groups and reduced glutathione. The effect of Nuclex on the acute and chronic hepatotoxicity models did not differ significantly by the investigated parameters from that of hepatoprotector Glutargine, which was used as a reference substance. 

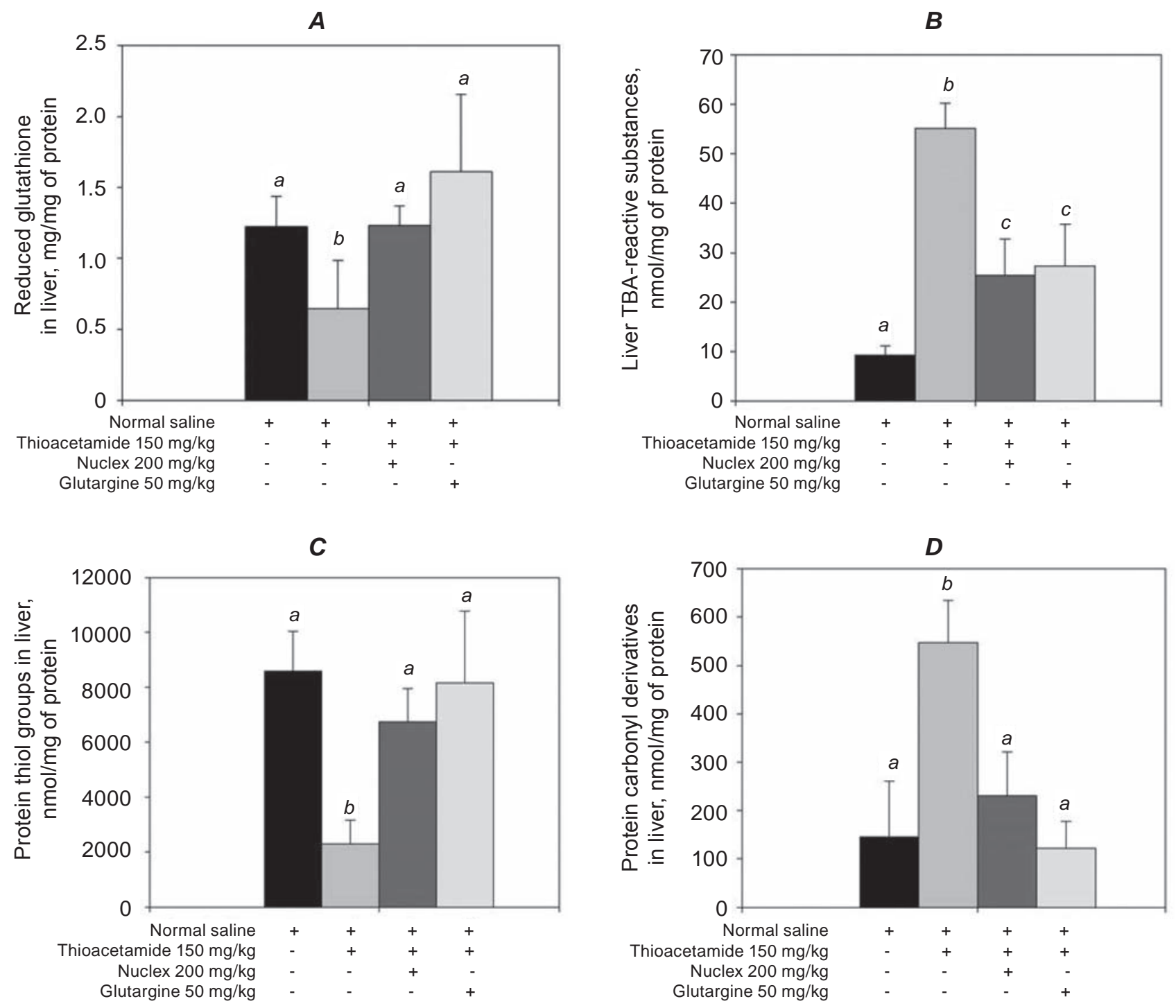

Fig. 4. Levels of products of oxidative damage to hepatic cellular biomolecules in mice under chronic thioacetamide-induced hepatotoxicity. Reduced glutathione (A), TBA-reactive substances (B), protein thiol groups $(C)$, and carbonyl derivatives (D) levels were determined in liver tissue post 9 week long course of intraperitoneal injection of normal saline and thioacetamide, and oral administration of Nuclex and Glutargine; the values indicated by letters $(a, b, c)$ differ significantly from each other 


\section{ГЕПАТОПРОТЕКТОРНА АКТИВНІСТЬ ЕКЗОГЕННОЇ РНК}

\author{
I. О. Шмараков ${ }^{1}$, T. В. Марчишак ${ }^{1}$, \\ В. Л. Борщзовецькка ${ }^{1}$ М. М. Марченко \\ 3. Ю. Ткачук ${ }^{2}$
}
${ }^{1}$ Чернівецький національний університет імені Юрія Федьковича, Україна; e-mail: igor.shmarakov@gmail.com; ${ }^{2}$ Інститут молекулярної біології і генетики НАН України, Київ; e-mail: ztkachuk@yahoo.com

Досліджували гепатопротекторну активність фармацевтичної композиції нуклекс, створеної на основі низькомолекулярної дріжджової РНК, у мишей за гострої та хронічної тіоацетамід-індукованої гепатотоксичності. Показано, що за гострого та хронічного ураження печінки за введення нуклексу у дозі 200 мг/ кг спостерігається виражений гепатопротекторний ефект, який супроводжується зниженням показників ураження паренхіми печінки та iï запальної інфільтрації. Застосування нуклексу призводить до атенуації тіоацетамідіндукованого вільнорадикального пошкодження біополімерів печінки, вираженого у зниженні рівня ТБК-активних продуктів, карбонільних похідних, а також до відновлення рівня протеїнових тіолових груп та відновленого глутатіону.

К л ю ч о в і с л о в а: нуклекс, тіоацетамід, гепатотоксичність, гепатопротекторна активність екзогенної PHК, миші лінії C57BL6/J.

\section{ГЕПАТОПРОТЕКТОРНАЯ АКТИВНОСТЬ ЭКЗОГЕННОЙ РНК}

\author{
И. А. Шмараков ${ }^{1}$, Т. В. Марчишак ${ }^{1}$ \\ В. Л. Борщиовечкая ${ }^{1}$ М. М. Марченко \\ 3. Ю. Ткачук ${ }^{2}$
}
${ }^{1}$ Черновицкий национальный университет имени Юрия Федьковича, Украина; e-mail: igor.shmarakov@gmail.com; ${ }^{2}$ Институт молекулярной биологии и генетики НАН Украины, Киев; e-mail: ztkachuk@yahoo.com

Исследовали гепатопротекторную активность фармацевтической композиции нуклекс, созданной на основе низкомолекулярной дрожжевой РНК, у мышей при острой и хронической тиоацетамидиндуцированной гепатотоксичности. Показано, что введение нуклекса в дозе 200 мг/кг при остром и хроническом поражении печени обладает выраженным гепатопротекторным эффектом и проявляется в снижении показателей поражения паренхимы печени и ее воспалительной инфильтрации. Применение нуклекса приводит к атенуации тиоацетамидиндуцированного свободнорадикального повреждения биополимеров печени, выраженного в снижении уровня ТБК-активных продуктов, карбонильных производных, восстановлении уровня протеиновых тиоловых групп и восстановленного глутатиона.

Ключевы е слов а: нуклекс, тиоацетамид, гепатотоксичность, гепатопротекторная активность экзогенной РНК, мыши линии C57BL6/J.

\section{References}

1. Sehgal A., Vaishnaw A., Fitzgerald K. Liver as a target for oligonucleotide therapeutics. $J$. Hepatol. 2013;59(6):1354-1359.

2. Tkachuk Z., Chajka L., Libina B. Experimental study of cardioprotective activity of ribonucleic acid in catecholamine myocardial infarction. News Farmakology and Farmacie. 2009;3(3):1419.

3. Germanyuk L. Yu., Demchuk M. V., Stadnik N. I. On the stimulating effect of injections of RNA on ribonucleotide synthesis and the functional state of the heart in dogs. Vopr. Med. Khim. 1965;11(6):34-38.

4. Kerr T. A., Davidson N. O. Therapeutic RNA manipulation in liver disease. Hepatology. 2010;51(3):1055-1061.

5. Tkachuk Z. Y. 2'-5'-Oligoadenylates as a "tool" of innate immunity. Biopolym. Cell. 2013;29(4):266-276.

6. Levchenko S.M. Rebriev A. V., Tkachuk V. V., Dubey L. V., Dubey I. Ya., Tkachuk Z. Yu. Studies on interaction of oligoadenylates with proteins in vitro by MALDI-TOF mass spectrometry. Biopolym. Cell. 2013;29(1):42-48.

7. Tkachuk Z. Y., Frolov V. M., Sotska Y. A., Kruglova O. V. Nuclex therapy for patients with chronic hepatitis C. Int. J. Immunological Studies. 2012;1(4):349-364.

8. Ge Q., Brichard S., Yi X., Li Q. MicroRNAs as a new mechanism regulating adipose 
tissue inflammation in obesity and as a novel therapeutic strategy in the metabolic syndrome. J. Immunol. Res. 2014;2014:987285.

9. Kozlov A. V., Kitam V. O., Tkachuk Z. Yu. Molecular model of the interaction of $2^{\prime}-5^{\prime}$ oligoadenylates with protein kinase C. Report of NAS of Ukraine. 2009;(3):171-175.

10. Tkachuk Z. U., Frolov V. M., Zelyoniy I. I., Afonin D. N., Tyutyunnik A. A. Influence of preparation nuclex on the cytokine profile of the patients with diabetes type 2 and neuropathic form of diabetic foot. Int. J. Diabetes Res. 2013;2(2):21-26.

11. Guide for the care and use of laboratory animals. Washington D. C.: National Academies Press, 2011. 246 p.

12. Shmarakov I. O., Borschovetska V. L., Marchenko M. M., Blaner W. S. Retinoids modulate thioacetamide-induced acute hepatotoxicity. Toxicol. Sci. 2014;139(2):284-292.

13. Schierwagen C., Bylund-Fellenius A. C., Lundberg C. Improved method for quantification of tissue PMN accumulation measured by myeloperoxidase activity. J. Pharmacol. Methods. 1990;23(3):179-186.

14. Ohkawa H., Ohishi N., Yagi K. Assay for lipid peroxides in animal tissues by thiobarbituric acid reaction. Anal. Biochem. 1979;95(2):351358.

15. Levine R. L., Garland D., Oliver C. N., Amici A., Climent I., Lenz A. G., Ahn B. W., Shaltiel S., Stadtman E. R. Determination of carbonyl content in oxidatively modified proteins. Methods Enzymol. 1990;186:464-478.

16. Murphy M. E., Kehrer J. P. Oxidation state of tissue thiol groups and content of protein carbonyl groups in chickens with inherited muscular dystrophy. Biochem. J. 1989;260(2):359-364.

17. Horyachkovskiy A. Clinical Biochemistry in laboratory diagnostics: A Reference Guide. Odessa: Ecology. 2005. 616 p.

18. Waterborg J. H., Matthews H. R. The Lowry method for protein quantitation. Methods. Methods Mol. Biol. 1994;32:1-4.

19. Hajovsky H., Hu G., Koen Y., Sarma D., Cui W., Moore D. S., Staudinger J. L., Hanzlik R. P. Metabolism and toxicity of thioacetamide and thioacetamide S-oxide in rat hepatocytes. Chem. Res. Toxicol. 2012;25(9):1955-1963.

20. Shapovalova I. A. Influence of nucleinas and $\alpha$-tokopherol combination on liver functional tests of the patients with chronic toxic hepatitis, combined with a chronic uncalculosis cholecystitis on background obesity. Ukr. Morpholog. Almanah. 2011;9(1):155-158.

21. Tkachuk Z. Yu., Tkachuk V. V., Tkachuk L. V. The study on membrane-stabilizing and anti-in flammatoryactions of yeast RNA in vivo and in vitro. Biopolym. Cell. 2006;12(2):109-116.

22. Hardisty J. F., Brix A. E. Comparative hepatic toxicity: prechronic/chronic liver toxicity in rodents. Toxicol. Pathol. 2005;33(1):35-40.

23. Saiman Y., Friedman S. L. The role of chemokines in acute liver injury. Front. Physiol. 2012;3:213.

Received 10.03.2015 